\title{
EKSPLORASI PERAN PEREMPUAN SAMIN DALAM MELESTARIKAN LINGKUNGAN ALAM (EXPLORING THE ROLES OF SAMIN WOMEN IN PRESERVING THE NATURAL ENVIRONMENT)
}

\author{
Ira Setyani ${ }^{1}$ \\ Fakultas Psikologi, Universitas Muria Kudus \\ catherine.chuang97@gmail.com \\ Alfian Yulistianto ${ }^{2}$ \\ Fakultas Psikologi, Universitas Muria Kudus \\ catherine.chuang97@gmail.com \\ Yusril Wicaksana Gunawan ${ }^{3}$ \\ Fakultas Pertanian, Universitas Muria Kudus \\ catherine.chuang97@gmail.com
}

\begin{abstract}
Women are part of the family who have the role to become educators as well as the first actors who understand how to maintain quality of life through the creation of a healthy environment in the family environment. Therefore, women's empowerment about the environment needs to be given to women. The Samin community is one of the Javanese indigenous people who have the ancestor Samin Surosentiko as their traditional leader. The journey of the Samin community has existed since the beginning of the Dutch colonial period and has survived to the present. This study examines the role of Samin women in preserving the environment. This study uses a qualitative phenomenological method approach. Data collection through interviews, observations and live-ins in the village of Samin. The results of this study state that Samin women undertake activities to care for the earth as a form of preserving the values of leahur and protecting the natural resources that have provided for them. Through the Sumber Warih organization, Samin women play an active role in protecting and caring for their environment both at home and in the Kendeng Mountains.
\end{abstract}

Keywords: environmental preservation, Samin, women's role.

\begin{abstract}
Abstrak
Perempuan adalah bagian dalam keluarga yang mempunyai peran untuk menjadi pendidik sekaligus pelaku pertama yang memahami bagaimana menjaga kualitas hidup melalui terciptanya lingkungan hidup yang sehat di lingkungan keluarga. Oleh sebab itu pemberdayaan perempuan tentang lingkungan hidup perlu diberikan kepada perempuan. Komunitas Samin merupakan salah satu masyarakat adat jawa yang mempunyai leluhur Samin Surosentiko sebagai tokoh adatnya. Perjalanan komunitas samin sudah ada sejak awal masa kolonial belanda dan bertahan hingga sekarang ini. Penelitian ini menganalisis bagaimana peran perempuan Samin dalam melestarikan lingkungan. Penelitian ini mengunakan pendekatan metode kualitatif fenomenologi. Pengumpulan data melalui wawancara, pengamatan dan live in di perkampungan Samin. Hasil penelitian ini menyatakan bahwa perempuan Samin melakukan aktivitas merawat bumi sebagai bentuk menjaga nilai-nilai lehur serta menjaga sumber daya alam yang telah menghidupi mereka. Lewat organisasi Simbar Warih perempuan Samin berperan aktif dalam menjaga dan merawat lingkungan mereka baik lingkungan rumah maupun lingkungan yang ada di Pegunungan Kendeng.
\end{abstract}

Kata kunci: pelestarian lingkungan, peran perempuan, Samin. 


\section{PENDAHULUAN}

Samin merupakan suatu perilaku yang nyeleneh sebagai bentuk pendekatan yang digunakan komunitas masyarakat untuk melawan para penjajah dimasa itu (Belanda dan Jepang). Perilaku nyeleneh ini diartikan seperti orang gila. Hal ini terus bertahan sampai saat ini, bahkan pada pemerintahan di era sekarang ini juga memiliki pandangan yang sama dengan stigma yang diberikan pada zaman penjajahan Belanda dan Jepang (Indaryani, 2017). Bagi orang Samin, bumi adalah ibu mereka yang murah hati dan terus menerus memberi hidup kepada anak-anak dan keluarganya. Warga Samin dengan keras melindungi alam dari siapapun yang akan merusaknya. Sikap-sikap yang akan merusak alam harus dicegah atau dihindari. Terutama sikap-sikap manusia yang akan merusak alam, harus dicegah. Sebagai bentuk organisasi formal perempuan dalam memelihara dan mempertahankan lingkungan hidup terdapat paguyuban simbar wareh yang berdiri di kawasan Gunung Kendeng. Paguyuban tersebut bertujuan untuk mempersatukan perempuan di Kabupaten Pati dan sekitarnya. Organisasi ini dalam konteks perjuangan perempuan untuk menolak keberadaan hal yang dapat merusak lingkungan (Indaryani, 2017).

Beberapa tahun terakhir, masyarakat Samin digencarkan dengan permasalahan pelestarian lingkungan yaitu, bersikukuh menjaga Pegunungan Kendeng dari berdirinya pabrik semen. Rencana pengoperasian pabrik semen yang memasuki wilayah Kendeng mendapatkan penolakan keras dari masyarakat adat Samin, khususnya dikalangan kaum perempuan. Respon dari gerakan menolak semen sangat massif dilakukan oleh perempuan-perempuan Kendeng yang dimotori oleh para kaum perempuan komunitas Samin. Beberapa aksi telah dilakukan perempuan Samin sebagai simbol kepedulian terhadap pelestarian lingkungan di tanah leluhur Pegunungan Kendeng. Aksi yang mendapatkan sorotan khalayak umum ketika para perempuan melakukan aksi menyemen kaki mereka di depan Istana Negara. Aksi tersebut dilakukan berulang-ulang kali, hingga banyak dari masyarakat luas menyatakan empati dengan aksi tersebut.

Dalam penelitian yang berjudul "Pandangan Orang Samin tentang Lingkungan Perspektif Vandana Shiva: Studi Kasus Pembangunan Pabrik Semen di Pegunungan Kendeng, Jawa Tengah", penelitian ini dilatarbelakangi oleh pengrusakan lingkungan hidup yang diakibatkan oleh pola pembangunan berwatak kapitalisme patriarki di negara dunia ketiga. Perempuan menjadi korban pembangunan, padahal perempuan banyak terlibat dalam gerakan penyelamatan lingkungan di dunia ketiga, termasuk di dalamnya perempuan Samin yang melakukan gerakan penyelamatan Pegunungan Kendeng dari pembangunan pabrik semen. 
Penelitian ini bertujuan untuk menganalisis bagaimana peran perempuan komunitas Samin dalam upaya menjaga kelestarian lingkungan dan sebagai bentuk gerakan ekofeminisme yang telah dilakukan para perempuan Samin.

\section{METODE}

Bogdan dan Taylor (Moleong, 2002) mendefinisikan metode kualitatif sebagai prosedur penelitian yang menghasilkan data deskriptif berupa kata-kata tertulis atau lisan dari orangorang dan perilaku yang dapat diamati. Metode kualitatif yang digunakan dalam penelitian ini adalah metode fenomenologis. Menurut Polkinghorne (Herdiansyah, 2010), mendefinisikan bahwa fenomenologi merupakan sebuah studi yang memberikan gambaran tentang arti dari pengalaman individu mengenai suatu konsep tertentu.

Sedangkan objek atau subjek dalam penelitian ini ialah tiga perempuan Samin di Kabupaten Pati yang dipilih dengan cara snowball. Desain pengumpulan data lapangan atau sumber-sumber data dikumpulkan menggunakan metode observasi secara langsung di tempat penelitian dan metode wawancara. Observasi adalah adanya perilaku yang tampak berupa perilaku yang dapat dilihat langsung oleh mata, dapat diukur serta dihitung dan adanya tujuan yang ingin dicapai (Herdiansyah, 2010). Gorden (Herdiansyah, 2010) berpendapat bahwa wawancara merupakan percakapan antara dua orang yang salah satunya bertujuan untuk mendapatkan dan menggali informasi untuk suatu tujuan tertentu. Dalam metode penelitian ini peneliti live in selama tiga hari di perkampungan Komunitas Samin di Desa Ngawen, Bombong dan Desa Galiran Sukolilo, Pati.

Menurut Bogdan dan Biklen (Moleong, 2007) menjelaskan bahwa koding data kualitatif merupakan proses sistematis dalam mencari dan mengolah berbagai data yang bersumber dari wawancara, observasi dan kajian dokumentasi untuk menghasilkan temuan penelitian. Dari uraian tersebut metode analisis data menggunakan koding melalui langkah awal dengan dua cara yaitu: peneliti membuat verbatim (kata demi kata) berdasarkan catatan lapangan, kemudian langkah kedua adalah peneliti melakukan penomoran pada baris-baris transkip dan catatan lapangan.

\section{HASIL DAN PEMBAHASAN}

Dalam penelitian ini peneliti melakukan live in selama tiga hari di kawasan perkampungan masyarakat Komunitas Samin di Desa Ngawen, Desa Bombong dan Desa Galiran, Kecamatan Sukolilo Kabupaten Pati. 
Masyarakat Komunitas Samin pada umumnya membaur dengan masyarakat biasa di lingkungan sekitarnya. Mereka berinteraksi baik dengan masyarakat selain orang-orang Samin. Pakaian mereka dalam sehari-hari juga sama seperti masyarakat pada umumnya. Yang membedakan masyarakat Samin dengan masyarakat lain adalah mayoritas dari masyarakat Komunitas Samin banyak menggunakan pakaian hitam-hitam dan mereka tidak mengenyam bangku sekolah formal. Selain itu, dalam berinteraksi masyarakat Samin cenderung memakai bahasa jawa krama kepada siapapun yang menjadi lawan interaksinya.

Ketika datang kerumah orang Samin membawa kesan bahwa komunitas ini merupakan komunitas yang sangat santun, ketika hendak bertamu orang-orang Samin menyambut dengan baik dan secara langsung memperkenalkan nama mereka. Hal berbeda pula ketika ada jamuan minuman, orang-orang Samin jarang menggunakan teh maupun kopi, orang-orang Samin membuat minuman dari hasil bumi mereka sendiri.

\section{Gambaran Subjek I}

Bumi iki siji ogak loro lan telu, bumi iku ibu. wong kuwi urip kan soko banyu, soko lemah seng iso menghasilkan pangan soko lemah, menghasilkan banyu yo soko lemah. Wong wedok kuwi malah seng bersentuhan langsung karo banyu. Yo kabeh bersentuhan tapi pada dasarnya niki seng kerja lipat/ kerja keras niki ibu-ibu seng ikut merasakan dampak niki ibuibu, mergo tangi turu niki buutuh air dan air bersih, kanggo masak, kanggo ngedusi anak-anak banyu iku omahe neng gunung, dadi engko nek omahe banyu dirusak dadine engko yo dampak soko iki

Subjek pertama ini merupakan salah satu tokoh perempuan penting dalam masyarakat Komunitas Samin. Yang paling ditonjolkan dari peran perempuan samin terhadap pelestarian lingkungan pada subjek pertama ini adalah menolak keras berdirinya pabrik semen di Pati. Subjek mengangap bahwa pendirian pabrik semen menjadi salah satu perusak lingkungan. Alasan utama subjek adalah hal tersebut menyangkut seluruh aspek kehidupan, subjek menilai orang hidup berawal dari tanah dan air maka, jika pabrik semen di dirikan tidak hanya tanah dan air saja yang akan hilang tetapi Pegunungan Kendeng akan terancam hilang. Sehingga subjek melakukan gerakan menolak pendirian pabrik semen, demi menyelamatkan bumi, yang dalam komunitas samin bumi dianggap sebagai ibu, sebab bumi telah memberikan sumbersumber kehidupan.

Dampak perusakan lingkungan orang yang paling merasakan dampak tersebut adalah para kaum ibu, menurut subjek, kaum perempuan yang paling dekat air, karena pada kondisi apapun perempuan sangat membutuhkan air setiap hari, seperti memasak, mandi hingga untuk 
keberhasilan bercocok tanam sangat memerlukan air yang cukup. Hal itu yang membuat para ibu-ibu Samin menolak keras pabrik semen yang akan merusak lingkungan Pegunungan Kendeng dari tahun 2009 sampai sekarang ini.

Subjek juga menjadi salah satu bagian dari organisasi Simberwarih, organisasi para perempuan Pegunungan Kendeng yang mengawal pelestarian lingkungan di Kendeng. Selain itu, subjek membuat minuman-minuman dari hasil bumi mereka sendiri, seperti halnya kunir asem, jahe, temulawak dan masih banyak lagi yang digunakan subjek sebagai salah satu bentuk kepeduliannya terhadap pelestarian lingkungan. Pelestarian lingkungan juga diajarkan di anakanak muda Samin, edukasi untuk anak-anak muda Samin dilakukan dengan cara melibatkan para anak-anak muda ketika ada rembug keluarga maupun rembug besar soal menjaga bumi. Hal ini yang menurut subjek yang membuat orang-orang komunitas samin akan terus menjaga ibu bumi.

\section{Gambaran Subjek II}

Subjek kedua merupakan masyarakat Komunitas Samin yang tinggal di Desa Galiran dan juga bergabung di organisasi Simberwareh. Subjek mengungkapkan bahwasannya menjaga kelestarian lingkungan adalah hal yang sangat penting untuk kehidupan. Subjek menjelaskan bahwa ada hal yang sederhana yang sering dilakukannya, yaitu dalam pengelolaan sampah rumah tangga. Subjek memilah-milah jenis sampah, jika sampah yang tidak digunakan dikumpulkan kemudian dibakar di halaman rumah subjek sendiri. Untuk sampah plastik yang masih bisa digunakan, subjek lebih memilih untuk tidak membuang sampah tersebut dan dipergunakan kembali. Kebanyakan di lingkungan subjek mengabaikan sampah-sampah rumah tangga, di lingkungan mereka banyak yang membuang sampah dimana-mana sehingga orang-orang Samin berinisiasi untuk membuat tempat pembuangan akhir (TPA) di lingkungan mereka.

Subjek juga mengajarkan anak-anaknya untuk tidak membuang sampah sembarangan, ketika di jalan tidak diperbolehkan membuang sampah di jalan, sampah tersebut harus dibawa dan dibuang pada tempat yang sudah disediakan.

Rasa peduli terhadap lingkungan bagi subjek sudah turun temurun, selain lingkungan yang bersentuhan langsung dengan bumi, lingkungan adat istiadat juga dipegang teguh oleh subjek. Seperti halnya ketika orang-orang melahirkan, orang-orang samin memegang teguh budaya jawa yang sudah diajarkan oleh sesepuh Samin. 


\section{Gambaran Subjek III}

Subjek ketiga merupakan masyarakat Komunitas Samin yang bertempat tinggal di Desa Ngawen Sukolilo Pati, subjek ikut berpartisipasi aktif di Simbarwareh.

Subjek juga menolak keras atas pendirian pabrik semen, bagi subjek pabrik tersebut akan membawa dampak menghilangkan beberapa sumber air yang selama ini dipakai masyarakat sekitar.

Kepedulian terhadap lingkungan juga dilakukan subjek ketika bercocok tanam. Subjek menggunakan pertanian organik ketika bercocok tanam, bagi subjek ketika bumi diperlakukan dengan baik maka bumi akan memberikan yang terbaik. Sehingga subjek tidak menggunakan bahan-bahan kimia di lahan pertanian. Pertanian organik dihasilkan subjek dari ternaknya sendiri, mengolah kotoran sapi menjadi pupuk dan pestisida alami.

Subjek juga menyatakan bahwa para perempuan Samin pada umumnya jarang menggunakan kosmetik, sebab di Samin banyak yang menggunakan bobok (kosmetik alami dari beras kencur) untuk merawat tubuh. Subjek juga menyadari bahwa sampah plastik kian banyak sehingga subjek melakukan pengurangan sampah plastik dengan cara membuat tas dari plastik untuk dibawa ketika belanja.

\section{Pembahasan}

Komunitas Samin memiliki ciri-ciri khusus yang menjadi identitas mereka dalam penampilan sehari-hari yang berbeda dengan masyarakat di sekitarnya. Identitas tersebut menunjukkan karakter dan perlengkapan mereka sesuai dengan ajaran Saminisme yang mereka pertahankan dari waktu ke waktu terutama generasi tua.

Mereka merasakan kebenaran dan keyakinan yang kuat terhadap ajaran-ajaran Samin Surosentiko sebagai pandangan hidup yang sangat berguna. Sikap dan perbuatan orang-orang Samin selalu diikuti bukti-bukti nyata dan konsekuen sesuai dengan ajaran yang diterima. Ciriciri khusus yang menjadi identitas masyarakat Samin antara lain terlihat dari pakaian dan bahasa yang digunakan.

Dalam masyarakat Komunitas Samin mempunyai pandangan tersendiri tentang alam. Menurut mereka bahawa bumi itu satau dan di ibaratkan sebagai ibu "bumi kui ibu Bumi iki siji ogak loro lan telu, bumi iku ibu. wong kuwi urip kan soko banyu, soko lemah seng iso menghasilkan pangan soko lemah, menghasilkan banyu yo soko lemah." Mereka berpandangan bahwa bumi telah memberikan banyak kehidupan bagi manusia, maka dari itu bumi harus dijaga dan dilestarikan untuk kehidupan manusia di bumi. 
Manusia di dalam kehidupannya sangat mengandalkan air, lahan, energi, keanekaragaman hayati dan ekosistem yang sehat untuk menjamin kelangsungan penghidupan mereka dan asset alam sangat penting untuk keluar dari kondisi pemiskinan. Banyak isu lingkungan yang tadinya berdiri sendiri sebagai isu lingkungan seperti perubahan iklim dan bencana, sekarang bergeser menjadi isu pembangunan secara umum dan politik karena luasnya dampak yang ditimbulkan semakin masif dan mempengaruhi hampir semua sektor kehidupan. Salah satu kelompok penerima dampak terbesar, jika kita bicara tentang lingkungan dan menurunnya fungsi layanan aset alam adalah perempuan.

Respon atas pembangunan yang menyentuh sumber daya alam mendapatkan respon dari kalangan perempuan Samin yang tergabung dalam organisasi Simberwareh. Bagi subjek pertama dan kedua bahwa kaum perempuan Samin meyakini bahwa pembangunan pabrik semen di Kendeng akan mengancam kelangsungan sumber daya alam di Pegunungan Kendeng. Subjek pertama mengungkapkan bahwa sumber bumi yang paling dibutuhkan adalah air, sebab air sangat dekat dengan kehidupan sehari-hari para perempuan Samin, sehingga mereka sangat menjaga kelestarian lingkungan untuk melindungi sumber daya air yang dimiliki. Begitupun dengan subjek kedua, kepeduliannya terhadap lingkungan membuatnya ikut bergabung aktif di Simberwareh bersama dengan subjek yang ketiga.

Perilaku menjaga kelestarian lingkungan telah ditunjukkan oleh perempuan Samin, seperti yang dilakukan subjek ketiga, bahwa sampah rumah tangga acap kali dihiraukan dan dibuang sembarangan. Tetapi hal tersebut berbeda dengan subjek ketiga, dia melakukan pengelolaan sampah sendiri dan tidak membuat tempat pembuang sampah tersendiri. Sampahsampah rumah tangga juga diberdayakan oleh subjek kedua, bahwa sampah plastik yang sering dibuang, dipergunakan kembali untuk mengurangi sampah plastik di lingkungan.

Disamping itu, perempuan atau ibu merupakan media edukasi pertama dan utama bagi anak-anaknya. Melalui ibu, pendidikan dan penyadaran tentang kepedulian terhadap lingkungan dapat ditanamkan pada anak-anak sejak dini. Dari penerapan pola hidup ramah lingkungan yang dilakukan dalam sebuah keluarga, anak akan terbiasa dalam menjaga lingkungannya. Jika kebiasaan dan kesadaran ini mengakar dalam diri anak-anak maka di masa depan akan terbentuk generasi yang peduli pada lingkungan.

Para perempuan Samin memanfaatkan sumber daya alam untuk dipergunakan dalam kebutuhan sehari-hari. Seperti yang dilakukan oleh subjek pertama dan kedua, mereka membuat dan mengkonsumsi minuman dari hasil pertanian kunir asem, temulawak dan jahe. Selain itu, mereka juga tidak terlalu memakai kosmetik, mereka cukup menggunakan beras 
kencur sebagai alat perawatan tubuh.

Pelibatan generasi muda juga telah ditunjukkan para perempuan Samin dalam mengedukasi lingkungan. Mereka melibatkan generasi muda ketika terdapat diskusi-diskusi persoalan merawat bumi, dari pertemuan itu para generasi samin dapat belajar secara langsung tentang bagaimana melestarikan lingkungan.

Terdapat gerakan yang sangat masif yang dilakukan para perempuan di komunitas Samin. Organisasi Simberwareh merupakan tempat para kaum perempuan dalam menyuarakan pendapatnya untuk menjaga kelestarian lingkungan di Pegunungan Kendeng. Upaya-upaya menjaga lingkungan telah dilakukan para perempuan samin dengan menolaknya pendirian pabrik semen di Kendeng. Para perempuan samin menolak keras pendirian pabrik tersebut karena akan memberikan dampak lingkungan yang akan menghilangkan sumber air yang selama ini menghidupi mereka.

Sebagai masyarakat adat, para perempuan samin telah melakukan upaya untuk menjalankan kearifan lokal yang ada di komunitas samin. Adat istiadat dipegang teguh sebagai pedoman hidup mereka termasuk dalam melestarikan lingkungan. Komunitas Samin mempunyai nilai-nilai tersendiri dalam menjaga bumi mereka, sebagaimana yang telah dilakukan leluhurnya dalam merawat bumi.

\section{SIMPULAN}

Perempuan adalah bagian dalam keluarga yang mempunyai peran untuk menjadi pendidik sekaligus pelaku pertama yang memahami bagaimana menjaga kualitas hidup melalui terciptanya lingkungan hidup yang sehat di lingkungan keluarga. Oleh sebab itu pemberdayaan perempuan tentang lingkungan hidup perlu diberikan kepada perempuan. Peran perempuan sangat diperlukan demi terjaganya bumi dari kerusakan-kerusakan material maupun gaya hidup.

Komunitas Samin sebagai masyarakat adat yang masih memegang teguh ajaran leluhurnya di Jawa, mempunyai nilai-nilai budaya tersendiri dalam berperilaku sehari-hari. Masyarakat Samin juga telah menunjukan eksistensinya sebagai masyarakat adat yang peduli terhadap lingkungan.

Para perempuan Samin di Sukolilo Pati berupaya menjaga ibu mereka yaitu alam semesta atau bumi mereka dari pendirian pabrik semen. Alasan kongkrit yang mereka monolak adalah akan ada dampak kerusakan alam terutama dalam pengelolaan air sebagai sumber kehidupan para masyarakat Samin. 
Melalui organisasi Simberwareh para perempuan Samin telah melakukan banyak hal sebagai bentuk menjaga dan merawat lingkungan. Organisasi ini juga sebagai media kampanye sekaligus media pemberdayaan perempuan dalam memanfaatkan sumber-sumber lingkungan hidup.

\section{DAFTAR PUSTAKA}

Agoes, S. (2010). Ilmu lingkungan, sarana menuju masyarakat berkelanjutan. Surabaya: Airlangga University Press.

Hubeis, A. V. S. (2010). Pemberdayaan perempuan dari masa ke masa. Bogor: IPB Press.

Darmastuti, A., Budiono, P., Maryanah, T., \& Handayani, W. H. (2012). Peningkatan kesadaran perempuan terhadap pengelolaan lingkungan wilayah pesisir di Kelurahan Bumi Waras (Seminar hasil-hasil penelitian dan pengabdian kepada masyarakat). Dies Natalis FISIP Universitas Lampung, Bandar Lampung.

Herdiasyah. (2010). Metodelogi penelitian kualitatif. Jakarta: Salemba Humanika.

Jurnal Perempuan No. 48 Tahun 2006, Berita, Pengetahuan Perempuan. Jakarta: Gramedia.

Munadjat, D. (1985). Hukum lingkungan (buku 11). Bandung: Nasional Binacit.

Widjanarko, M., Indaryani, M., \& Indriani, F. (2004). Peran perempuan dalam pengelolaan lingkungan hidup di Kabupaten Kudus (ISSN: 0261-5341) [Laporan Penelitian, Puslitbang UMK-Pusat Kajian Gender dan Pemerintah Kabupaten Kudus]. Warta APTISI Wilayah VI Jawa Tengah.

Woromukti, D., \& Maharani, S. D. P. (2016). Pandangan orang samin tentang lingkungan perspektif Vandana Shiva: Studi kasus pembangunan pabrik semen di Pegunungan Kendeng, Pati, Jawa Tengah. Jurnal Universitas Gadjah Mada. Yogyakarta. 